September 7, 1984

\title{
Financing Current Account Deficits
}

The current account of the U.S. international balance of payments marked a record $\$ 41$ billion deficit in 1983 and will reach new heights this year, perhaps as high as $\$ 100$ billion. This reprèsents a remarkable deterioration from the $\$ 25$ billion current account surplus recorded in 1981.

Because our current account deficit represents the excess of U.S. import purchases over export sales of goods and services (and net transfers), it must be financed by a net inflow of foreign funds. The institutional channels through which foreign funds have recently been flowing into the U.S. are identified in the capital account of the balance of payments. This Letter shows where the foreign capital inflows into the U.S. are coming from, explains how present patterns differ from past episodes with financing our currenct account deficits, and considers the outlook.

\section{The capital account}

The capital account of the balance of payments is the record of the financial transactions of a nation with the rest of the world, and may be thought of as the counterpart of the real sector transactions (payments and receipts for goods and services plus transfers) represented by the current account.

Capital account transactions are recorded in the balance of payments statistics as the change in the foreign asset holdings of U.S. residents and the change in the U:S. asset holdings of foreign residents (where "resident" includes individuals, institutions and governments). The purchase of U.S. assets by foreign residents is a foreign capital inflow into the U.S., and the purchase of foreign assets by U.S. residents is a capital outflow from the U.S. For example, the $1983 \$ 41$ billion U.S. capital account surplus (or net capital inflow - current accountdeficit) means that, on balance, foreigners purchased $\$ 41$ billion more U.S. assets than U.S. residents purchased of foreign assets.

The capital account is divided between government and private sector transactions because of their generally different motivations for buying and selling foreign assets. Government sector transactions are termed official capital flows and, for the most part, represent official sales and purchases of foreign currencies as governments attempt to influence exchange rate values. U.S. government sales (purchases) of foreign assets and foreign governments' purchases (sales) of U.S. assets are capital inflows (outflows) into the U.S.

In addition, several components of private capital flows are separated by the institution involved or the nature of the transaction itself. The available statistics distinguish among four basic types of private capital flows: 1) claims on foreigners reported by U.S. banks (capital outflow from U.S.) and U.S. liabilities to foreigners reported by U.S. banks (capital inflow to U.S.); 2) purchases of foreign securities by private U.S. residents (capital outflow) and purchases of U.S. securities - both U.S. Treasury securities and other U.S. securities - by private foreign residents (capital inflow); 3) U.S. direct investment in foreign businesses (capital outflow) and foreign direct investment in U.S. business operations (capital inflow); and 4) all other gross international asset transactions involving U.S. residents or U.S. assets. International capital flows may thus take a variety of forms - private or government asset transactions, bank capital flows, direct investment, direct security purchases of sales, and so on. An important point is that the net capital inflow (outflow), or capital account surplus (deficit), exactly offsets, or "finances," a current account deficit (surplus).

\section{History and the present}

Over the past 25 years, the United States recorded a measurable deficit on the current account in only six years: $1971-72,1977-78$, and 1982-83. Besides the present episode, the current account deficits were large (adding up to $\$ 30$ billion in 1977-78) only in 1977 and 1978. Thus, on balance, the U.S. has traditionally been in the position of a net exporter of capital to abroad (incurring a capital account deficit) by running current account surpluses.

The financing patterns from the few previous episodes do nevertheless provide a stark contrast with the present circumstances. In particular, in the 1971-72 and 1977-78 episodes, U.S. current account deficits were associated with large private capital outflows. Official capital inflows financed both U.S. current account deficits and substantial private capital outflow from the U.S. during those 
years. (In 1977 , for example, the $\$ 14.5$ billion current account deficit and $\$ 18.2$ billion net private capital outflow were financed by a $\$ 32.7$ billion net official capital inflow into the U.S.). Official capital inflows during these years resulted primarily from the U.S. Treasury selling foreign currency reserves and foreign governments purchasing U.S. government securities in their attempts to stem the fall of the dollar in the foreign exchanges.

In contrast, although the U.S. current account marked a substantial $\$ 9.2$ billion deficit in 1982 and an unprecedented $\$ 41$ billion deficit in 1983, the dollar has appreciated in the foreign exchanges, and there has been a net official outflow of capital from the U.S. (including U.S. government assets other than official reserves). Thus, unlike previous episodes with current account deficits, private capital inflows in 1982-83 have offset both our current account deficits and an official capital outflow from the U.S.

The present willingness of the private sector to finance massive current account deficits contrasts with previous episodes with deficits and points to the different nature of the economic policies now being pursued. In particular, our present policy mix - an expansionary fiscal policy that is not accompanied by an expansionary monetary policy and favorable business and investment tax treatment - has created an environment of high nominal interest rates, a modest short-term inflation outlook, and a good business outlook relative to abroad. These conditions have provided strong incentives for net private capital inflows.

In contrast, the 1971-1972 period with current account deficits saw a significant net private capital outflow, largely in response to investors' concerns over an overvalued dollar -its strength artificially maintained by official exchange market intervention operations. Similarly, the 1977-78 episode with large U.S. current account deficits also saw a large flight of private capital from our shores. In that instance, investors lost confidence in the expressed resolve of U.S. officials to bring down the inflation rate. The result was a portfolio shift out of U.S. dollar-denominated assets and a run on the dollar. This was again met by massive exchange market intervention undertaken by the Carter Administration and foreign governments.
Composition of private capital flows in 1983 In 1983, the official statistics recorded an unprecedented $\$ 33$ billion private capital inflow. Because of the massive "errors and omissions" category in the balance of payments statistics in 1982 , showing an unrecorded $\$ 33$ billion inflow of funds into the U.S., it has not been possible to identify the channels during that year through which private capital flowed into the U.S. In 1983, however, the "errors and omissions" component declined to a more manageable $\$ 9.4$ billion unrecorded inflow of foreign funds.

The unprecedented private capital inflow in 1983 nevertheless represents an extraordinary $\$ 56$ billion turnaround from the $\$ 23$ billion recorded private capital outflow in 1982. The recorded net private capital flows in 1982 and 1983 and its components are shown in the accompanying chart. Foreign flows into the U.S. stock and bond markets (net securities) in 1982 continued in 1983, increasing somewhat. In addition, moderate amounts of net inward direct investment (at a slower rate than in 1982) were also recorded.

By far the most important component of the private capital inflow, however, was a massive switch in the direction of banking transactions between the Eurodollar market and the domestic money markets. Specifically, the swing in bank flows from a $\$ 45$ billion outflow in 1982 to a $\$ 24$ billion inflow in 1983 -accounted for 73 percent of the total recorded private capital inflow in 1983. This turnaround is extraordinary (amounting to a $\$ 71$ billion reversal), particularly in light of the net outflows through the banking system for every year but two (1969 and 1979) of the last 25 years. Furthermore, first quarter 1984 statistics indicate that bank capital inflows (at $\$ 9.4$ billion) are continuing to finance the bulk of our $\$ 19.4$ billion current account deficit and to make up the lion's share of recorded private capital inflows.

\section{Causes of bank inflows}

The recent swing in bank flows resulted from the sharp $\$ 84$ billion drop-off in loan volume to foreigners by U.S. banks - from $\$ 109$ billion in 1982 to only $\$ 25$ billion in 1983 . However, gross liabilities to foreigners, i.e., borrowing from foreigners, reported by U.S. banks also declined over the 1982 rate of increase by $\$ 13$ billion in 1983. Nevertheless, foreign borrowings by U.S. banks in 1.983 remained fairly strong by historical standards at $\$ 51$ billion. Other statistics show that 
Private Capital Flows: 1983/1982 Comparison

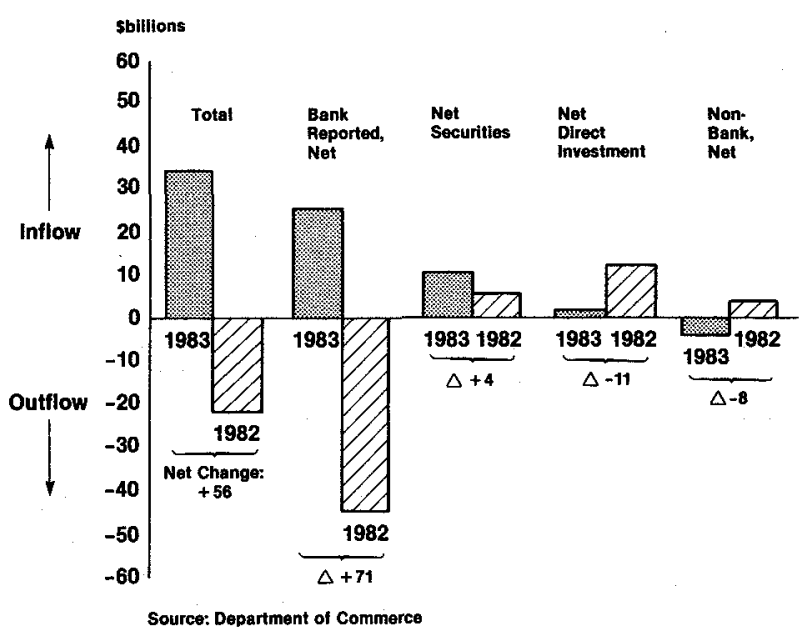

these funds were generated primarily from U.S. bank branches in major financial centers around the world gathering Eurodollar deposits that were then borrowed by parent banks in the U.S. In addition, U.S. banks in 1983 borrowed significant amounts from unaffiliated foreign banks and from nonbank foreigners.

Thus, although U.S. bank liabilities to foreigners (borrowings) slowed somewhat in 1983, a dramatic reversal from bank capital outflow to inflow nevertheless resulted because of the 80 percent dropoff in U.S. bank loans to their own branches abroad, to unaffiliated banks abroad and to foreigners directly from domestic offices (including from International Banking Facilities - IBFs).

Although the 1982 U.S. bank loan figures are inflated somewhat because of the rebooking of offshore loans to newly created IBF facilities within the U.S., this decline between 1982 and 1983 is nevertheless significant.

Major U.S. commercial banks in 1983 were largely responsible for channeling net funds inflows into the U.S. because of their established presence in worldwide money markets, large scale of operations and recent desire to divert lending from foreign to domestic borrowers. Thus, they were in a key position to take advantage of high domestic interest rates in channeling funds to the U.S. from abroad.

\section{Outlook}

Recent developments in the Eurodollar markets indicate that the direct sales of U.S. securities to foreigners-particularly U.S. Treasury bondscould play an increasingly important role in directing foreign funds into the United States. This development has been spurred both by the sheer volume of Treasury debt that needs to be marketed and the elimination of the 30 percent U.S. withholding tax on interest accruing to foreign holders of U.S. securities.

The movement of traders from more than a dozen government securities firms in New York to London in the last nine months indicates their intensified sales efforts in new markets and with new buyers overseas. In addition, European investment bankers would like to see the U.S. Treasury create a special class of securities tailored to foreign buyers. The European banks have argued that foreign individuals represent the biggest untapped source for Treasury securities because foreign institutional buyers were never seriously inhibited by the U.S. withholding tax (they often paid the tax and received a tax credit from their own governments).

In sum, there is some indication that direct sales of U.S. securities to foreigners may increase in the future as a proportion of total U.S. net private capital inflows. Without a shift in U.S. and foreign fiscal and monetary policies, substantial net private capital inflows are likely to continue financing large U.S. current account deficits - although the composition of U.S. assets held by foreigners may vary - and official capital flows will likely play a secondary role.

Michael Hutchison

Opinions expressed in this newsletter do not necessarily reflect the views of the management of the Federal Reserve Bank of San Francisco, or of the Board of Governors of the Federal Reserve System.

Editorial comments may be addressed to the editor (Gregory Tong) or to the author .... Free copies of Federal Reserve publications can be obtained from the Public Information Department, Federal Reserve Bank of San Francisco, P.O. Box 7702, San Francisco 94120. Phone (415) 974-2246. 
voj6u!Ysom youn vo6əנо ороләU

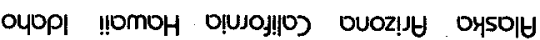

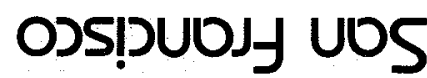

jo YणOg

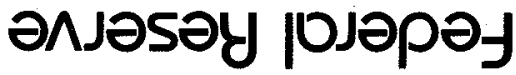

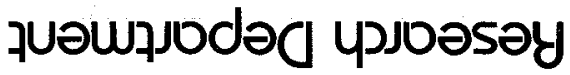

BANKING DATA—TWELFTH FEDERAL RESERVE DISTRICT

(Dollar amounts in millions)

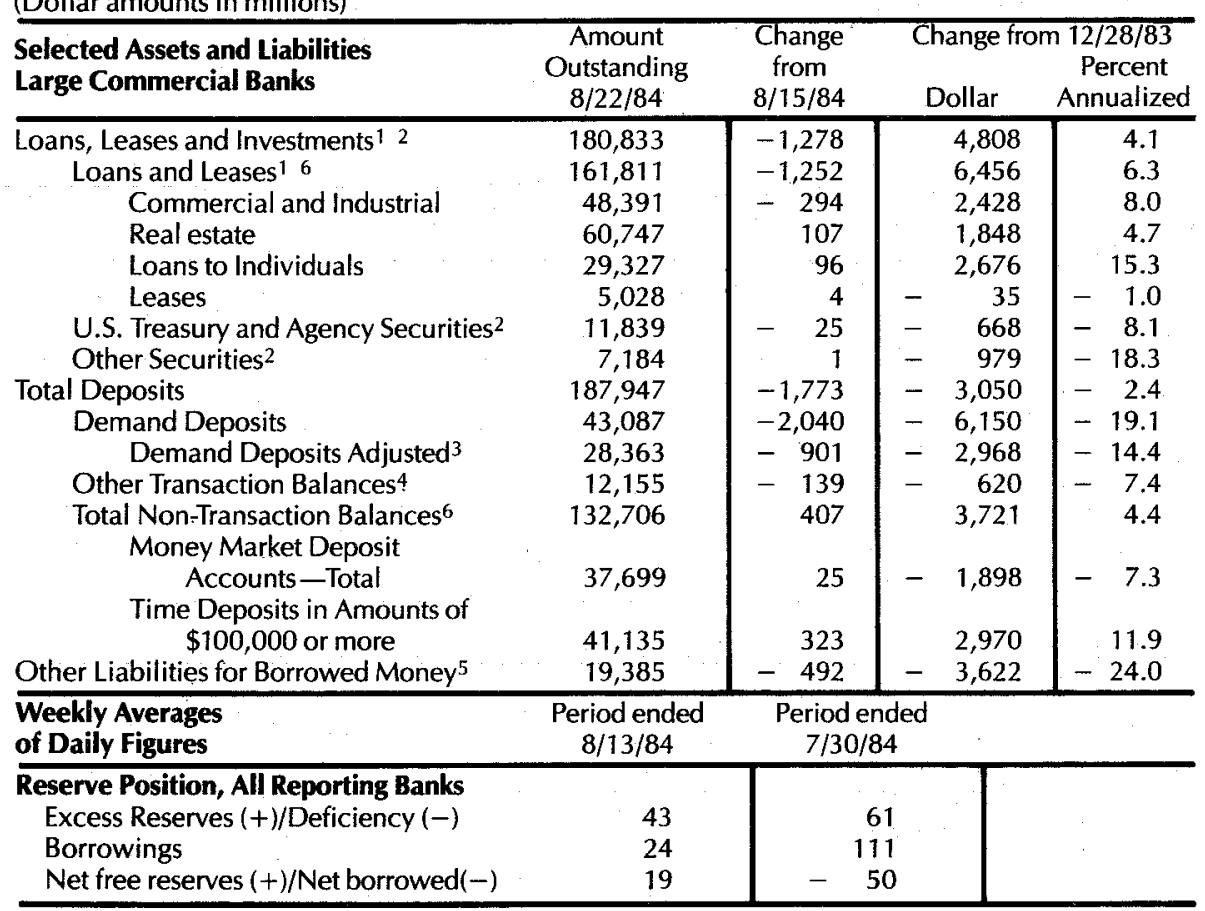

1 Includes loss reserves, unearned income, excludes interbank loans

2 Excludes trading account securities

3 Excludes U.S. government and depository institution deposits and cash items

4 ATS, NOW, Super NOW and savings accounts with telephone transfers

5 Includes borrowing via FRB, $\Pi \& L$ notes, Fed Funds, RPs and other sources

6 Includes items not shown separately 